\title{
The regulation and role of neuronal gap junctions during development
}

Andrei B. Belousov

Department of Molecular and Integrative Physiology; University of Kansas Medical Center; Kansas City, KS USA

Key words: gap junctions, connexin 36, metabotropic glutamate receptors, GABA receptors, neuronal death, development, electrical synapses

Abbreviations: CNS, central nervous system; Cx36, connexin 36; GABA $\mathrm{R}$, $\gamma$-aminobutyric acid A receptor; mGluR, metabotropic glutamate receptor; NMDA, N-methyl- $D$-aspartate; NRSE, neuron-restrictive silencer element

Submitted: 05/08/11

Accepted: 05/08/11

DOI: $10.4161 /$ cib.4.5.16380

Correspondence to: Andrei B. Belousov; Email:abelousov@kumc.edu

Addendum to: Park WM, Wang Y, Park S, Denisova JV, Fontes JD, Belousov AB. Interplay of chemical neurotransmitters regulates developmental increase in electrical synapses. J Neurosci 2011; 31:5909-20; PMID: 21508216;

DOI: 10.1523/JNEUROSCI.67.
$\mathrm{C}$ Coupling of neurons by electrical ${ }_{\text {synapses (gap junctions) transiently }}$ increases in the mammalian CNS during development and plays a role in a number of developmental events, including neuronal death. The coupling subsequently decreases and remains low in the adult, confined to specific subsets of neurons. In a recent study we have demonstrated that the developmental increase in neuronal gap junction coupling is regulated by the balance between the activity of two neurotransmitter receptors, group II metabotropic glutamate receptors (mGluR) and $\mathrm{GABA}_{\mathrm{A}}$ receptors. Specifically, we found that activation of group II mGluRs induces the developmental increases in neuronal gap junction coupling and expression of connexin $36(\mathrm{Cx} 36$; neuronal gap junction protein) and activation of $\mathrm{GABA}_{\mathrm{A}}$ receptors counteracts to these increases. We also established that the regulation by both neurotransmitter receptors is via a neuron-restrictive silencer element in the $\mathrm{C} \times 36$ gene promoter and the 3'-untranslated region of the $\mathrm{Cx} 36$ mRNA. Importantly, we demonstrated that mechanisms for the developmental increase in neuronal gap junction coupling directly control the death/survival mechanisms in developing neurons.

Transient coupling of large groups of neurons by electrical synapses (gap junctions) is a general phenomenon in the developing mammalian central nervous system (CNS): it has been documented in different regions of the CNS (neocortex, hippocampus, hypothalamus, striatum, locus coeruleus, spinal cord, etc.,) and in different species (rat, mouse, ferret, opossum, etc.). ${ }^{1}$ Neuronal gap junction coupling increases during late embryonic and/or early postnatal development and plays an important role in a number of developmental events, including neuronal differentiation, cell death, cell migration, synaptogenesis and neural circuit formation. ${ }^{2-8}$ The coupling decreases during later stages of development, which occurs in response to increasing chemical synaptic (glutamatergic) transmission and activation of $N$-methyl-D-aspartate (NMDA) receptors.?

Recently, we characterized the mechanisms that are responsible for the developmental increase in neuronal gap junction coupling and the role of these mechanisms in the regulation of death/survival mechanisms in developing neurons. ${ }^{10}$ The experiments were conducted in developing neuronal cultures prepared from the rat and mouse hypothalamus and cortex and in the hypothalamus of developing rats in vivo. We established the role for two neurotransmitter receptors: group II metabotropic glutamate receptors (mGluR) and $\gamma$-aminobutyric acid $A$ receptors $\left(\mathrm{GABA}_{\mathrm{A}} \mathrm{Rs}\right)$ (Fig. 1). Specifically, using dye coupling, electrotonic coupling, western blots and small interfering RNA, we showed that a prolonged ( 2 week) activation of group II mGluRs augments, and inactivation prevents, the developmental increases in neuronal gap junction coupling and expression of connexin 36 (Cx36; neuronal gap junction protein). However, changes in $\mathrm{GABA}_{\mathrm{A}}$ receptor activity had the opposite effects. We also established that the regulation by group II mGluRs is via cAMP/PKA-dependent signaling pathways (that are negatively coupled to the group II mGluRs ${ }^{11}$ ) and the regulation by $\mathrm{GABA}_{A} \mathrm{Rs}$ (which are excitatory during development ${ }^{12}$ ) is via 


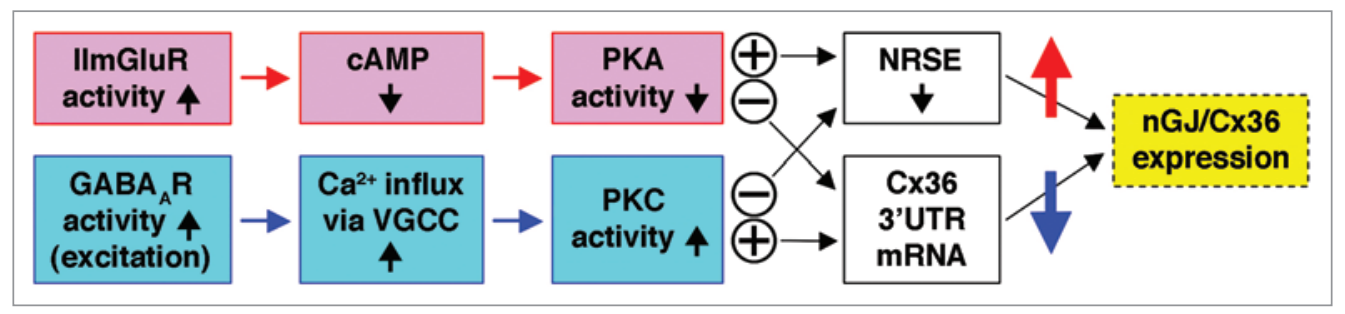

Figure 1. Simplified model of mechanisms for the developmental increase in neuronal gap junction coupling and connexin 36 expression in the mammalian CNS. Note that in developing neurons, the $\mathrm{GABA}_{\mathrm{A}} \mathrm{R}$-dependent pathway is excitatory and causes cell depolarization and $\mathrm{Ca}^{2+}$ influx. $\mathrm{CAMP}$ cyclic AMP; GABA ${ }_{A} R, G A B A_{A}$ receptor; IlmGluR, group II metabotropic glutamate receptor; $\mathrm{nGJ} / \mathrm{C} \times 36$, neuronal gap junction coupling and connexin 36 ; NRSE, neuron-restrictive silencer element; PKA, protein kinase A; PKC, protein kinase C; 3'UTR, 3'-untranslated region; VGCC, voltage-gated Ca ${ }^{2+}$ channels; $\oplus$, activation of group II mGluRs or $\mathrm{GABA}_{A} \mathrm{Rs} ; \ominus$, inactivation of group II mGluRs or GABA $\mathrm{Rs} ; \mathbf{4}$, increase; $\downarrow$, decrease. See text for details.

$\mathrm{Ca}^{2+}$ influx through voltage-gated $\mathrm{Ca}^{2+}$ channels and activation of protein kinase C (Fig. 1). We also showed that other glutamate receptors, acetylcholine receptors and $\mathrm{GABA}_{B}$ receptors are not involved in these regulatory mechanisms. Moreover, agonists and antagonists of group II mGluRs and GABA ${ }_{\mathrm{A}}$ Rs did not affect the expression of $\mathrm{Cx} 43$ (that is a presumptive glial connexin ${ }^{13}$ and also increases during development ${ }^{9}$ ), suggesting that the regulation is specific for neuronal, but not glial gap junctions. Moreover, neither developmental nor receptor-dependent increases in neuronal gap junction coupling were observed in Cx36-deficient neurons, suggesting that this regulation is exclusive for Cx36.

Neuron-restrictive silencer element (NRSE) is a DNA sequence element in a promoter region of a number of neuronal genes (including the Cx36 gene) that binds RE1-silencing transcription factor and regulates the transcriptional activity of these genes. ${ }^{14,15}$ Our results with the use of reverse-transcription quantitative real-time polymerase chain reaction and luciferase reporter activity analysis suggested that the receptor-dependent increase in Cx36 expression, that is mediated in developing neurons by activation of group II mGluRs or inactivation of $\mathrm{GABA}_{\mathrm{A}} \mathrm{Rs}$, is regulated via removal of the NRSE-dependent repression of the Cx36 gene promoter activity. In contrast, the receptor-dependent decrease in $\mathrm{Cx} 36$ expression, that is mediated by inactivation of group II mGluRs or activation of $\mathrm{GABA}_{A}$ Rs, likely involves posttranscriptional mechanisms dependent upon sequences within the 3'-untranslated region of the Cx36 mRNA (Fig. 1).
In the developing CNS, programmed cell death helps to establish the final number of neurons and contributes to distribution of various cell classes and neuronal circuit formation. ${ }^{16}$ The activity of NMDA receptors also is the factor that plays a role in cell survival versus death decisions during neuronal development. ${ }^{17,18}$ It has been suggested that during development gap junctions are involved in the regulation of apoptosis ${ }^{19}$ and NMDA receptor-dependent neuronal death. ${ }^{8}$ In our study, using methyl thiazolyl tetrazolium assay in developing rat hypothalamic and mouse cortical cultures, we found that prolonged activation of group II mGluRs, that augments the developmental increase in neuronal gap junction coupling, also makes neurons significantly more susceptible to the NMDA receptor-mediated excitotoxicity. At the same time, prolonged inactivation of group II mGluRs, that prevents the developmental increase in neuronal gap junction coupling, also completely prevents the NMDA receptor-mediated neuronal cell death. This suggests that mechanisms for the developmental increase in neuronal gap junction coupling directly regulate death/survival mechanisms in developing neurons.

Altogether, the results revealed a multitiered strategy for developing chemical synapses in regulation of electrical synapses. The results also indicated an important role for the mechanisms of regulation of gap junction coupling in the control of death mechanisms in developing neurons.

\section{Acknowledgments}

I thank the contributors to this study: Won-Mee Park, Dr. Yongfu Wang, Dr. Soodong Park, Janna V. Denisova and Dr.
Joseph D. Fontes. This research was supported by NIH (R01 NS064256).

\section{References}

1. Bennett MV, Zukin RS. Electrical coupling and neuronal synchronization in the Mammalian brain. Neuron 2004; 41:495-511.

2. Bani-Yaghoub M, Underhill TM, Naus CC. Gap junction blockage interferes with neuronal and astroglial differentiation of mouse P19 embryonal carcinoma cells. Dev Genet 1999; 24:69-81.

3. Lin JH, Weigel $\mathrm{H}$, Cotrina ML, Liu S, Bueno E, Hansen AJ, et al. Gap-junction-mediated propagation and amplification of cell injury. Nat Neurosci 1998; 1:494-500.

4. Allen F, Warner A. Gap junctional communication during neuromuscular junction formation. Neuron 1991; 6:101-11.

5. Walton KD, Navarrete R. Postnatal changes in motoneurone electrotonic coupling studied in the in vitro rat lumbar spinal cord. J Physiol 1991; 433:283-305.

6. Peinado A, Yuste R, Katz LC. Extensive dye coupling between rat neocortical neurons during the period of circuit formation. Neuron 1993; 10:103-14.

7. Personius K, Chang Q, Bittman K, Panzer J, BaliceGordon R. Gap junctional communication among motor and other neurons shapes patterns of neural activity and synaptic connectivity during development. Cell Commun Adhes 2001; 8:329-33.

8. de Rivero Vaccari JC, Corriveau RA, Belousov AB. Gap junctions are required for NMDA receptor-dependent cell death in developing neurons. J Neurophysiol 2007; 98:2878-86.

9. Arumugam H, Liu X, Colombo PJ, Corriveau RA, Belousov AB. NMDA receptors regulate developmental gap junction uncoupling via CREB signaling. Nat Neurosci 2005; 8:1720-6.

10. Park WM, Wang Y, Park S, Denisova JV, Fontes JD, Belousov AB. Interplay of chemical neurotransmitters regulates developmental increase in electrical synapses. J Neurosci 2011; 31:5909-20.

11. Conn PJ, Battaglia G, Marino MJ, Nicoletti F. Metabotropic glutamate receptors in the basal ganglia motor circuit. Nat Rev Neurosci 2005; 6:787-98.

12. Stein V, Nicoll RA. GABA generates excitement. Neuron 2003; 37:375-8.

13. Rash JE, Staines WA, Yasumura T, Patel D, Furman CS, Stelmack GL, et al. Immunogold evidence that neuronal gap junctions in adult rat brain and spinal cord contain connexin-36 but not connexin-32 or connexin-43. Proc Natl Acad Sci USA 2000; 97:7573-8. 
14. Martin D, Tawadros T, Meylan L, Abderrahmani A, Condorelli DF, Waeber G, et al. Critical role of the transcriptional repressor neuron-restrictive silencer factor in the specific control of connexin 36 in insulin-producing cell lines. J Biol Chem 2003; 278:53082-9.

15. Cicirata F, Parenti R, Spinella F, Giglio S, Tuorto F, Zuffardi O, et al. Genomic organization and chromosomal localization of the mouse Connexin36 (mCx36) gene. Gene 2000; 251:123-30.

16. Nijhawan D, Honarpour N, Wang X. Apoptosis in neural development and disease. Annu Rev Neurosci $2000 ; 23: 73-87$.
17. Scheetz AJ, Constantine-Paton M. Modulation of NMDA receptor function: implications for vertebrate neural development. FASEB J 1994; 8:745-52.

18. de Rivero Vaccari JC, Casey GP, Aleem S, Park WM, Corriveau RA. NMDA receptors promote survival in somatosensory relay nuclei by inhibiting Bax-dependent developmental cell death. Proc Nat Acad Sci USA 2006; 103:16971-6.
19. Cusato K, Bosco A, Rozental R, Guimaraes CA, Reese BE, Linden R, et al. Gap junctions mediate bystander cell death in developing retina. J Neurosci $2003 ; 23: 6413-22$ 